\title{
LEGACIES
}

Members will be aware that a legacy to a Charity such as the Royal College of Psychiatrists' Appeal Fund is exempt from Capital Transfer Tax up to a maximum amount of $£ 100,000$, including other similar legacies or gifts made within one year of death.

A legacy is therefore a useful method of supporting the Fund, by providing for such a future gift. A member wishing to include an appropriate clause in a Will may find the following standard wording helpful:

"I bequeath to the Royal College of Psychiatrists' Appeal Fund the sum of $£$ and direct that the receipt of the Honorary Treasurer of the College for the said legacy of $£ \quad$ shall be a full and sufficient discharge to my executors in respect thereof".

\section{DEED OF GOVENANT}

Any member already contributing regularly to the Appeal Fund, or a member prepared so to do in the future, may wish to cover such contributions by a deed of covenant, thereby increasing the value of the contribution to the Fund, usually at no cost to the donor. The form reproduced below may be used for completion of such a deed and when completed should be detached and returned to the Honorary Treasurer, The Royal College of Psychiatrists, 17 Belgrave Square, London SW IX 8PG.

\section{Deed of Covenant}

I/We

of hereby covenant with the ROYAL COLLEGE OF PSYCHIATRISTS (The College) that for a period of seven years from the day of 19................ or during my lifetime (whichever period shall be the shorter) I/We will pay each year/quarter to the said College such a sum as will after deduction of Income Tax at the basic rate for the time being in force leave in the hands of the said College a sum which will amount to $f$..............

$$
\text { (.........................................................................................) such sum to be paid from }
$$
my general fund of taxed income so that I shall receive no personal or private benefit in either of the said periods from the said sum or any part thereof.

IN WITNESS whereof I have hereunto set my hand and seal this day of 19

SIGNATURE(S) OF CONTRIBUTOR(S)

SIGNED AND SEALED AND DELIVERED BY THE ABOVE IN THE PRESENCE OF

SIGNATURE OF WITNESS

ADDRESS 